\section{World leaders must act now to prevent next pandemic, warns Global Preparedness Monitoring Board}

\author{
Ingrid Torjesen
}

Time is running out for world leaders to act to end the current covid-19 pandemic and to introduce measures to prevent future pandemics, the Global Preparedness Monitoring Board (GPMB) has said.

In its 2021 report the board issued a stark warning that the "window of opportunity to make meaningful change" was closing quickly as the world's attention turned to other issues.

The report, launched at the World Health Summit in Berlin on 26 October, ${ }^{1}$ urges leaders to take political responsibility for the widespread transformation needed in the health emergency ecosystem and to act immediately-before the end of this year-to demonstrate their commitment and intent.

Hundreds of recommendations have been made over the past two decades to reform the global response to health emergencies, the GPMB said, but they were not acted on. Even in the past year meetings of the UN General Assembly, the UN Security Council, the World Health Assembly, G7 leaders, and G2o leaders have achieved little more than declarations of intent.

Elhadj As Sy, co-chair of the board, wrote, "It is easy to be cynical and think that nothing can change, that inequality, inaction, and division are unavoidable, that the models of the past cannot be exchanged for better ways of working together that benefit all, that we are forever condemned to repeat this cycle of panic and neglect.

"But we must reject pessimism, recognize our common humanity and growing interdependence, and create a global health ecosystem that serves everyone. Together we must move from worlds apart to a world prepared."

\section{Critical actions}

The report identifies six critical actions needed for a safer world. These include strengthening global governance through an international agreement on health emergency preparedness and response, with sustainable and flexible financing, while building a stronger World Health Organization and creating an agile and equitable health emergency system. These actions must be underpinned by empowering communities, engaging civil society and the private sector, and strengthening independent monitoring and mutual accountability, it says.

The GPMB said that action should begin with WHO member states agreeing at the World Health Assembly next month on the need to adopt an international agreement and establish a process for taking that forward. This should be followed before the end of the year by the UN General Assembly agreeing to convene a summit of heads of state and government, it advised, and the WHO Working Group on
Sustainable Financing agreeing a significant increase in the WHO assessed contributions, as recommended by the UK's Foreign Affairs Committee last month. ${ }^{2}$

An additional financial intermediary fund should be set up within the World Bank to provide additional funding for international preparedness and response, the report says, through a formula based on equity and countries' ability to pay, supplemented by the private sector.

Finally, by the end of the year WHO member states should develop terms of reference for research, development, and equitable access to common goods, learning lessons from the inequity of access to vaccines and other goods during the covid-19 pandemic. ${ }^{3}$ WHO set a target of vaccinating at least $10 \%$ of the population in each country against covid-19 by the end of September 2021, a goal reached by almost $90 \%$ of high income countries but not a single low income country.

The report concludes that covid-19 has exposed a broken and divided world in which access to vaccines depends on ability to pay rather than need, where governments, leaders, and institutions are too unaccountable to their populations, and where societies are fragmented, nationalism is growing, and geopolitical tensions are rising.

\footnotetext{
Global Preparedness Monitoring Board. From worlds apart to a world prepared: GPMB 2021 report. 26 Oct 2021

https://www.gpmb.org/docs/librariesprovider17/default-document-library/gpmb-annual-report-2021.pdf?sfvrsn=44d10dfa_9

2 Torjesen I. The UK should take the lead in pushing for reform of WHO, MPS say. BMJ2021;374:n2404. doi: 10.1136/bmj.n2404 pmid: 34593520

3 ACT-Accelerator. ACT-Accelerator strategic review: an independent report prepared by Dalberg. 8 Oct 2021. https://www.who.int/publications/m/item/act-accelerator-strategic-review
}

This article is made freely available for use in accordance with BMJ's website terms and conditions for the duration of the covid-19 pandemic or until otherwise determined by BMJ. You may use, download and print the article for any lawful, non-commercial purpose (including text and data mining) provided that all copyright notices and trade marks are retained. 